\title{
Countering Violent Extremism
}

Journal Issue

Author(s):

Sokirianskaia, Ekaterina; Kurbanova, Lydia U.; Gurevich, Victoria; Dzeitova, Mareta

Publication date:

2020-07-14

Permanent link:

https://doi.org/10.3929/ethz-b-000426379

Rights / license:

$\underline{\text { In Copyright - Non-Commercial Use Permitted }}$

Originally published in:

Russian Analytical Digest (RAD) 255 


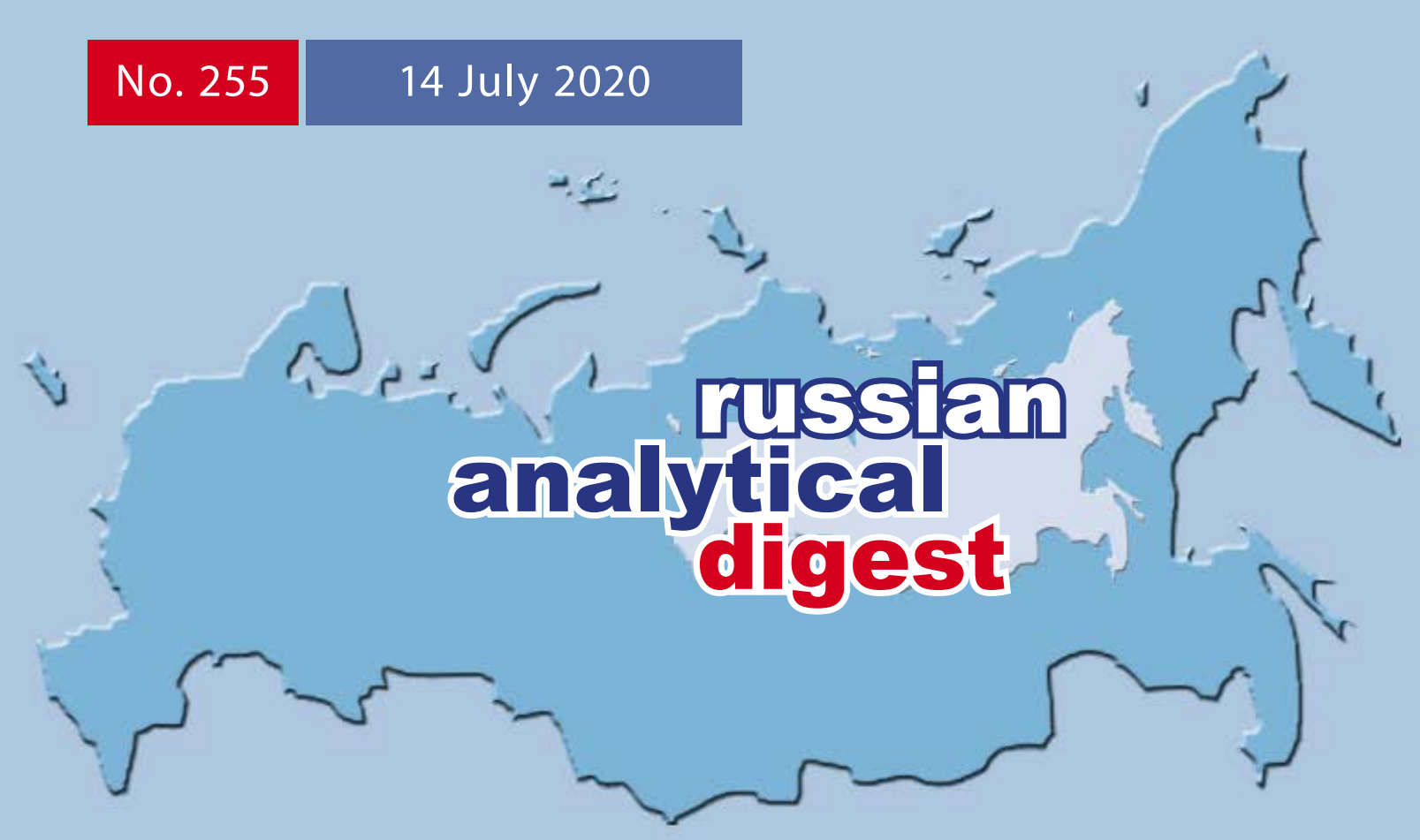

\section{COUNTERING VIOLENT EXTREMISM}

\section{ANALYSIS}

Countering Violent Extremism among North Caucasus Youth

By Ekaterina Sokirianskaia, Conflict Analysis and Prevention Center

\section{ANALYSIS}

"Why Is It so Easy to Seduce Us?"

Young Female Students' Narratives of Extremist Online Recruitment

By Lydia U. Kurbanova, Chechen State University, Grozny

\section{ANALYSIS}

The Potential of Families in Countering Violent Extremism in the North Caucasus

By Victoria Gurevich, The Ohio State University, Columbus

ANALYSIS

Preventing Violent Extremism in the North Caucasus:

The Case of the Regional Project "Together!" ("Vmeste!")

By Mareta Dzeitova, Ingush State University, Magas 


\title{
Countering Violent Extremism among North Caucasus Youth
}

By Ekaterina Sokirianskaia, Conflict Analysis and Prevention Center

DOI: $10.3929 /$ ethz-b-000426379

\begin{abstract}
Armed conflict in the North Caucasus, one of the most protracted and deadly struggles in Europe, has significantly quieted in recent years. However, the root causes and underlying grievances that were feeding the violence have not been addressed, thus the threat of re-escalation is real. Being aware of this possibility, the Russian government has been developing radicalization prevention programs focusing on North Caucasus youth. This article analyzes the general approaches to countering violent extremism work that have been implemented in the North Caucasus through various government and non-governmental agencies, highlighting some of the best practices, the most serious challenges, and offering policy recommendations.
\end{abstract}

\section{Countering Violent Extremism in the North Caucasus: Mapping the Field}

For nearly three decades since the collapse of the USSR, the North Caucasus has been riven by instability and armed conflict. The conflict has taken different forms and has passed through various degrees of intensity including two full-blown wars between the federal military and separatists in Chechnya, and then protracted armed struggle between a regional Islamist insurgency and the security services across the region. Between 2012-2017, large numbers of jihadists from Russia travelled to Syria and Iraq. These individuals were predominantly from the North Caucasus. According to Russia's FSB chief, Alexander Bortnikov, 5,500 Russian citizens travelled abroad to join international terrorist groups. ${ }^{1}$

As a result of the mass outflow of radicals to the Middle East and the decline and military defeat of the North Caucasus insurgency before the Sochi Winter Olympics, the security situation in the region has significantly quieted. However, since none of the root causes and underlying grievances of the armed conflict have been addressed, the threat of re-escalation of violence remains real. Being aware of this possibility, in recent years, the Russian government has been supplementing its traditionally heavy-handed approaches of counter-terrorism with prevention programs. This article will focus on ideological preventive work with youth in the context of the North Caucasus republics most affected by armed conflict-Chechnya, Dagestan, Ingushetia and Kabardino-Balkaria (KBR). It is based on research and fieldwork conducted in the region in 2018-2019.

\section{Official CVE in the North Caucasus}

Russia's country-wide system of ideological prevention of terrorism and extremism is federally led, bureaucratized and involves various government and non-gov- ernment agencies and actors. The 2009 "Response to Terrorism Concept" defines the key principles and priorities of countering terrorism that include, inter-alia: the principle of "inevitability" of punishment for terrorismrelated crimes, ideological propaganda for anti-terrorism, and an emphasis on "socially meaningful" values.

"The Comprehensive Plan for Countering the Ideology of Terrorism in the Russian Federation for 20192023", designed as a supplement to the Concept, highlights the need "to carry out prevention work with individuals affected by terrorism and also implement measures aimed at forming an anti-terrorism consciousness among the population by means of information propaganda". The "Strategy of Countering Extremism in the Russian Federation for 2015-2025" also defines ideological prevention as propaganda in education establishments, mass media, cultural institutions.

In the North Caucasus the republics develop their own programs on countering the ideologies of extremism and terrorism in compliance with federally defined priorities. Due to regional diversity, different intensities of armed conflict, and differing political climates, Countering Violent Extremism (CVE) efforts vary quite significantly. They usually involve officials from youth policy ministries and committees, ministries of education and sports, local municipalities, republican Spiritual Boards of Muslims (quasi-government religious institutions uniting government-approved imams and mosques) and pro-government NGOs. Recently some independent NGOs have also made their way into the CVE community.

Counter-narratives are the basis of youth CVE work across the North Caucasus. Counter-narratives have been defined as "an intentional and direct effort to deconstruct, discredit, and demystify violent extremist messaging through ideology, logic, fact or humor"

1 https://www.kommersant.ru/doc/4126739 (accessed 13 May 2020). 
(Hemmingsen and Castro: 2017). Effective counternarratives should be context specific, designed for a given target group, and most importantly, delivered by credible messengers. In the North Caucasus counter-narratives are usually straightforward and emotional propaganda.

The largest scale of preventive work has unfolded in Chechnya, which is understandable given its history of protracted deadly conflict. Counter-narratives in Chechnya are mainly disseminated by Chechen officials, law-enforcement, and imams. They carry out massive propaganda work through the media, internet and at face-to-face meetings, organized at universities, schools, colleges, and in village communities, including distant mountain villages. The main target is youth and teenagers, although some propaganda also reaches out to the adults.

Many of my respondents noted that the CVE propagandists often resort to threatening rhetoric in Chechnya. "When the security services come to talk to the kids, they are threatening them. The imams are also aggressive because Chechen Republic Head Ramzan Kadyrov is threatening the imams. Responsible officials are afraid that they will be beaten and fired if anything happens on the territory under their control. So, they come into the classroom charged with this negative energy, which comes top-down," a Chechen expert explained to me.

Official counter-narratives are much softer in the other republics. For example, the Ministry of Youth in Dagestan has a special prevention unit consisting of former civil society activists close to the Spiritual Board of Muslims. This unit has developed a welldesigned training course called "Peaceful Dagestan," which travels around Dagestan's towns and villages and is presented at various events. The presentation contains colorful slides which tell the history of Dagestan, show its natural beauty, explain the geopolitical challenges the republic is facing, and introduce the notion of jihad and what it really means in Islam. This training has reached out to tens of thousands of young people aged 14-30 across the republic. The Ministry of Youth has also produced an anti-ISIS propaganda documentary, called ISIS: An Eastern Trap, which has received over 500,000 views on YouTube.

Similarly, in Ingushetia, the Committee for Youth Matters designed a training course called "DISlike Extremism" for high school, college and vocational school students. It aims to discuss internet security, the dangers of terrorist ideology, and various mechanisms of recruitment.

In Dagestan the officials are reluctant to engage youth in debate. The Ministry of Youth staffers explained to me that their lectures do not include Q\&A sessions in order to keep the situation from getting out of con- trol. "Initially, we had 30 minutes for Q\&A at the end, but then we decided not to do it anymore... Debates break out, tensions emerge and they forget everything they were being told for 1-1.5 hours. The effect of the lecture is gone. So, we tell them: here is a website where you can learn more, here's your local imam who can answer questions. And we close this way." Unlike Dagestan, the Ingush "DISlike of Extremism" program has an extensive Q\&A section.

In Kabardino-Balkaria meetings in municipalities, universities and schools, youth fora, and village gatherings against extremism often feature Soviet-style engagement with children and youth. Many follow similar scenarios: municipal officials, clergy, and pro-government NGO activists make speeches and play videos condemning terrorism and extremism, while pupils and students present their essays or drawings, or recite patriotic poems. Recently however, some of the CVE officials in KBR have reportedly started reaching the understanding that direct confrontational counter-narratives are not effective and they have begun trying to offer alternatives. Being a multi-ethnic republic, Kabardino-Balkaria also organizes ethnic tolerance activities aimed at overcoming tensions and fostering dialogue.

The authorities across the region promote counternarratives in cooperation with the military-patriotic clubs and the Russian Guard and military. Special summer camps for military trainings for members of the Youth Army (Yunarmia) are organized for children aged 14-16 in Dagestan. Another format is the "Search Movement" which engages young people in expeditions where they excavate the relics of the Second World War in other regions of Russia.

These activities are seen as an alternative engagement, a way to distract and channel the youth's energy into patriotic activities. Local schools are also required to place significant emphasis on patriotic education, which often means the glorification of military victories and the heroization of war veterans.

Another channel for youth engagement is "the volunteer movement", which is currently part of the official youth policy across Russia. Volunteers are encouraged to get involved in socially meaningful depoliticized projects, such as environmental protection, education and healthcare. The federal center distributes funds for volunteer initiatives through the regional governments and during various regional and federal fora, the most important one for the North Caucasus being the forum Mashuk which in 2018 was attended by Vladimir Putin. In some places, the volunteer organizations are doing highly valuable work and are genuinely attracting young people, while in many other places, they mostly exist on paper, and are mobilized administratively when needed. 


\section{Imams and NGOs for CVE}

CVE work often involves representatives of the Spiritual Board of Muslims and imams. My youth interlocutors however, were quite skeptical about their impact, as one student from Makhachkala explained: "They (the representatives of the Spiritual Board) cram us into the class, 150 people, maybe one or two students are listening to them, some are playing with their phones, others are doing homework for the next class... Every month or so they come, sometimes it is interesting, but mostly they cannot present things attractively."

In Chechnya, imams who visit schools, colleges and universities present religious arguments asserting that Chechens have all of the necessary conditions to practice their faith in Chechnya - that Chechnya is the land of Islam, with hundreds of mosques, Islamic dresscodes and Islamic morality enforced by authorities. They always praise the Kadyrov family and explain that Islam obliges Muslims to support their ruler. Imams combine anti-extremist and political propaganda; for example, by praising President Putin or campaigning for elections. The fact that the mullahs have become the main ideological force of the regime prevents them from being seen as independent and credible messengers by many young Chechens.

Interestingly in Dagestan, which is probably the most conservative of all the North Caucasus republics with the strongest Islamic tradition, many schools had until recently managed to keep imams out of the classrooms. This can be explained by the fact that the republican education ministry and many school principals still belong to the old Soviet generation of educators who are either atheists or believe that religion and the state should be clearly separated. One school principal told me that she doesn't let religious propaganda into her school as she thinks the role of imams in preventing violent extremism in counter-productive, they impose their (Sufi) strand of Islam on others and thereby deepen intra-confessional divisions between believers.

In Ingushetia, critical imams, including moderate law-abiding Salafis, can speak in mosques and thereby produce counter-narratives from their religious positions that are much more convincing for the already radicalizing youth. One such imam is the charismatic Khamzat Chumakov who has reportedly talked almost 70 people out of going to Syria. Moderate Salafi voices speaking against ISIS used to be heard in Dagestan as well; however, in the last several years most of the Salafi mosques were closed, while moderate Salafi imams who spoke about ISIS were threatened by the security services, ISIS, or both.

The key problem identified by all interlocutors is that many of the CVE engagements are often tedious. "It's so boring that after these sessions, radicalization only increases," one educator joked. Professionals who work with the youth in Chechnya emphasize that the aggressive and straightforward propaganda in this republic has the reverse of the intended preventive effect. "The more they blame ISIS, the more interest the youngsters have in it. It becomes attractive, romanticized," a former university professor from Grozny told me.

Several NGOs across the region have also started to focus on CVE and their work is done in a more creative and professional way than the government-inspired initiatives. In Chechnya, one of the NGOs with links to the Chechen government involves widows returned from ISIS in youth trainings. This is a welcome development: the stories of these women are the most convincing counter-narratives for youth who are susceptible to radical propaganda. Ingush Genesis Fund is implementing methodologically sophisticated trainings in several North Caucasus republics, while the Chechen NGO "Women for development" tries to reach out to women and offer CVE preventive trainings and support to vulnerable women and girls.

NGO activists and independent experts note a lack of trainings in critical thinking and the absence of free and meaningful discussions of the radicalization process in the region. "There are no such authentic discussions because in the end, we will anyway come to the conclusion that we would not have such problems if we had free media, independent courts and real elections," the leader of the Kabardino-Balkar Human Rights Center told me.

Indeed, apart from educators, the government still primarily trusts pro-government, patriotic organizations and the traditional clergy, however, these messengers miss a significant portion of the youth who do not find them credible. Still, the massive nature of CVE work in the region has brought some clearly positive resultsmost of the young people have internalized that the ideas promoted by extremism and terrorism are strongly condemned by their society, its dominant strand in Islam and state and are strictly punishable by law.

\section{CVE and Root Causes of Radicalization}

One of the main problems with the current CVE approaches in the North Caucasus are that they are based on the assumption that a violent ideology can be defeated by counter-propaganda. This can partly be true, but the root causes and factors conducive to radicalization are numerous and diverse. Counter-narratives presuppose a simple causal relation between ideology and violent actions and do not address various other individual, social and political factors that are conducive to radicalization.

For years the highly resilient insurgency in the North Caucasus has been feeding on radical ideologies and some material support from abroad, but has primarily 
been sustained by domestic push factors: memories of the two wars in Chechnya, heavy-handed counter-insurgency practices across the region, unresolved intra-confessional and ethnic conflicts, political repression, low quality of governance, a lack of democratic procedures, economic underdevelopment and a dearth of social lifts.

Jihadism manipulates young people's psychological problems, issues with peers, conflicts with parents, their desire for adventure, and pressures of the traditional society. The latter is particularly prominent with young women. A widow returned from ISIS recently explained to me her motives to join ISIS in an interview. She left right after turning 18 and in her own words was looking for an adventure:

"I had everything_-studies, sufficient income, a job. I was studying well. But I lacked in adrenalin, it was childhood maximalism, I am crazily agile. I wasn't afraid to die and thought 'if it bombs, it bombs'."

Yet, it becomes clear from her story that her escape to Syria was also a protest, a striving for self-realization and recognition:

"Since my childhood I wanted to work for the FSB (Federal Security Service)... I wanted to wear a uniform and shoulder straps. But my father said: 'My daughter will never be a member of the security services, this is not a woman's job'. Then after school I passionately desired to become a surgeon. But my father chose another profession for me- a construction engineer. I was hysterical, but I couldn't go against his will. I had conflicts with my parents over the hijab. They didn't accept it. Back then I didn't think about my parents, I was angry at them. Now I wouldn't

have ever done it. I've reconsidered everything." Experts claim that supportive families, exciting activities aimed at self-realization, timely management of psychological problems, quality relations with peers and parents, socialization that provides connectedness, opportunities for adventure, and a sense of purpose are conducive to the successful transition to adulthood (Harper: 2018). Much of it can be created by effective youth policy through the educational system and with civil society programs.

In the North Caucasus it would be important to consider supplementing and even replacing counter-narratives with alternative narratives and engagements. For example, creating new opportunities for self-realization for the youth outside the government-controlled military-patriotic format; facilitating modern and trendy activities; and creating more opportunities for girls and women to participate in them. Open debates about difficult subjects, where constructive, productive and feasible ways of engaging with challenging political issues can be identified, should be encouraged. Human rights volunteering and engaging in other uncontrolled social and political activism will help to positively and constructively channel frustrations within the framework of law.

It would be equally important to improve the quality of counter-narratives by making them creative and youth-friendly. Involving credible messengers from among respected public figures, educators, activists, sportsmen, and peers will significantly increase the impact of CVE work. At the same time, CVE cannot replace sustainable conflict resolution which one day will have to take place in order for new waves of radicalization to be prevented.

\section{About the Author}

Ekaterina Sokirianskaia, Ph.D., is founder and director of the Conflict Analysis and Prevention Center (CAPC), a new think-and-do tank established in 2017. CAPC's mission is to provide nuanced and accurate field-based analysis of and solutions to violent conflicts in Russia and the post-Soviet space.

\section{Bibliography}

- Anne-Sophie Hemmingsen and Karin Ingrid Castro (2017) The Trouble with Counter-Narratives, DIIS Report 1, Danish Institute for International Studies, Copenhagen.

- Erica Harper (2018) Reconceptualizing the Drivers of Violent Extremism: An Agenda for Child and Youth Resilience, WANA Institute.

- Arie Kruglanski, Michele Gelfand, Jocelyn Bélanger, Malkanthi Hetiarachchi, and Rohan Gunaratna (2015) “Significance Quest Theory as the Driver of Radicalization towards Terrorism.” In Resilience and Resolve: Communities Against Terrorism, London: Imperial College Press.

- Kamaldeep Bhui, Sokratis Dinos, and Edgar Jones (2012) "Psychological Process and Pathways to Radicalization." Journal of Bioterrorism and Biodefense.

- Katarzyna Jasko, Arie Kruglanski, Ahmad Saiful Rijal Bin Hassan, Rohan Gunaratna (2019) "ISIS: Its History, Ideology, and Psychology." In Handbook of Contemporary Islam and Muslim Lives, Cham: Springer.

- "Violent Mobilization and Non-Mobilization in the North Caucasus." Perspectives on Terrorism, Special Issue, 14(2), 2020 . 


\title{
"Why Is It so Easy to Seduce Us?" Young Female Students' Narratives of Extremist Online Recruitment
}

\author{
By Lydia U. Kurbanova, Chechen State University, Grozny
}

DOI: $10.3929 /$ ethz-b-000426379

\begin{abstract}
The article analyzes the rhetoric of third-year female students of Chechen State University related to the online recruitment of women into extremist organizations. The author analyzes the attitudes of the young women, the levels of their fear/anxiety about online recruitment, and documents the main discourses and rhetoric regarding female departures to Syria and Iraq. Focus groups showed that the rhetoric of unreasonableness is the dominant way that female departures to the Middle East are perceived. "Weak" and "easily manipulatable", women who are "crushed by housework and domestic violence" are contrasted to "experienced and smart" manipulators-recruiters who pull them into terrorist networks. Given that the problem of radicalization in Chechnya remains acute, the author advocates for greater contributions from gender psychologists and discourse analysis professionals to research the phenomenon of female online recruitment in the North Caucasus context.
\end{abstract}

\section{Young People in the Chechen Republic}

Young people have often been hostages of circumstance of both contemporary and previous generations' ideological activities and transformations. Young people of the Chechen Republic, in particular, have come of age in a turbulent time in the history of their country-in the midst of geopolitical conflicts, social and economic reforms, and moral and spiritual confrontations. Contemporary Chechen society is characterized by high polarization and social and ideological polymorphism, under which the attitudes and value systems of individuals representing the same ethnic culture have diverged in different directions. The impact of violent extremism on some youngsters, typically exposed through the Internet, is considerable and requires vigorous theoretical and empirical approaches for analysis. In this article the motivations of young people, especially girls, to join extremist organizations, are analyzed through the lens of students' daily discourses that emerged around this issue.

\section{Explaining Research Methods}

The subject of this research are female students, the object-their discourses about other girls who joined violent extremist organizations though online communications. The spectrum of attitudes was determined by the extent to which the "departures to Syria" of their peers were problematized or de-problematized by the respondents. It allowed me to measure the attitudes of the youth, the level of fear/anxiety among the girls about online recruitment, as well as to understand the main discourses and rhetoric regarding female departures and the meanings produced by them.

Before proceeding to the empirical analysis concerning the rhetoric and attitudes surrounding "departure", it is important to clarify what is meant by the broader concept of "social problems", of which departure to Syria is a component. There are two main approaches by which to consider and analyze social issues. The first approach argues that there exist objective circumstances that represent a threat to society. Here, researchers refer to such concepts as "social pathology", "social disorganization", "deviation", "dysfunction", and "structural contradiction" (Jenkins 2003, 49). The second approach is based on the idea that the "problem" has no ontological basis, that it is a linguistic construction of a rhetoric containing change requirements. It develops within the framework of social constructionism (Jenkins 2003).

There are also researchers who study the ways of constituting a social problem through discourse (Holstein and Gubrium 2008; Polach 2010). The main focus of their attention are the "methods used by people to define (and institutionalize) anything as a social problem, since it is precisely these methods that essentially constitute the phenomenon of social problems" (Ibarra and Kitsuyuz 2007, 55). Despite the multitude of theories offered by media discourse, lived experiences and reality rarely come into the view of researchers; in particular, few research projects analyze everyday interpretations of terrorism.

One of the few examples of such research is provided by Klas Borell, which describes the quotidian practices and representations of people living in a territory subject to terrorist attacks (Borell 2008). In his work, Borell does not rely on a constructivist paradigm and does not seek to analyze constructs articulated by his subjects. Instead, his work focuses on providing a description of everyday interpretations of "danger" and "safety" as associated with these phenomena. The data obtained 
allows us to trace how public discourse is transformed through the influence of personal experience and how it changes everyday practices. Rhetorical idioms are the means by which public discourse is problematized. Ibarra and Kitsuyuz describe rhetorical idioms such as rhetorics of loss, empowerment, danger, foolishness and disasters (Ibarra and Kitsuyuz 2007, 72-84). In recent years, the constructivist approach has turned towards the everyday realm.

As Ibarra and Kitsuyuz note, "the discourse of social problems is encountered in all kinds of forums and among the widest circle of persons" (Ibarra and Kitsuyuz 2007, 106). Some constructivists are trying to analyze the construction of social problems which are "less visible, disguised in various ways - for example, due to the use of subcultural style-but are no less involved in expressing one's position in relation to moral ordering or commenting on the positions of others" (Ibarra and Adorjan 2017).

\section{Why Are Young Girls Leaving for Syria?}

My goal in this research is to reconstruct the daily discourse of university students related to the problem of "young girl's departure to Syria" as a result of recruitment through social media and the internet. Two focus groups with 18 and 21 participants, respectively, were carried out involving Chechen State University Law Faculty third-year students. The interview guide included several semantic blocs measuring interests, values, the frequency of online communications, online publications of personal data in social networks, as well as the level of comfort/security and discomfort/danger related to online recruitment and departures.

The focus groups found that female students have neither anxiety while discussing this issue nor use disaster rhetoric. In some cases, they demonstrated elements of bewildered (rather than anxious) rhetoric: "they say they force [women] to marry the militant after the death of the husband, that's so strange..."

The respondents' rhetoric was also colored with feelings of pity and concern: "I feel sorry for [their] relatives and moms", "now, what should be done with the children who were born during the war?"

This kind of rhetoric does not mean that respondents do not recognize the potential danger of online recruitment; they do, but they feel fully confident that recruitment only happens to naive and romantic girls, or those from dysfunctional families, and that it would not affect them personally.

"I think it's stupid to believe beautiful online stories, although some people are naive, so they

lap it up" (respondent, 19 y/o).

Some respondents have personal experience of such recruitment attempts:
"My boyfriend told me all the time that a true Muslim should give their life for the faith. But when he asked if I would go with him [to Syria], I told him it is impossible without our parents' blessings, eventually he stopped our communication. I heard later that he was gone, maybe he left, I don't know" (respondent, 18 y/o).

The tension felt during the focus groups was palpable; several factors could explain this, though we believe two are the most important. First, the issue of radicalization is extremely securitized in Chechnya; as such, there is a significant fear to be too frank in judgments due to the security services' close control over any manifestations of "loyalty" to extremists. Second, "preventive measures" such as lectures and conferences on terrorism and extremism issues are often held in educational establishments; participants may have been suspicious of our focus groups as being connected to official republican programming. Official rhetoric is based on threats, sanctions, and publicly stigmatizing the relatives of the people who left for Syria, blaming them for "allowing this to happen", "not preventing" the situation, or "raising their kids badly". Therefore, the students were reluctant to share opinions evaluating any particular cases. It is clear that the risk of sparking the interest of law enforcement or exposing their acquaintances to the special services' scrutiny was a significant reason for them to be reserved in their comments.

Some statements could be described as deliberate reproductions of official discourse, of "the correct narrative", in order to protect oneself and avert any suspicion of having sympathy for the girls who had left.

- "I'm sorry for their mothers and relatives" (respondent, 20 y/o)

- "These girls disgraced their families, forefathers, and nation, how could they? I don't feel sorry for them, they had to think for themselves, how dare they?" "Did the girls really care about their parents or relatives? It seems to me they don't love the republic or the motherland in general" (respondent, 20 y/o)

\section{"Rhetoric of Unreasonableness"}

Focus groups showed that the rhetoric of unreasonableness is the dominant way of problematizing the recruited girls' departures. As Ibarra and Kitseyuz posit, the use of this rhetorical idiom depends on the ability to describe the situation in terms that highlight concerns about exploitation, manipulations, and brainwashing. In the framework of this rhetoric, the recruited women were described as "trusting", "naive", "easily manipulatable", "submissive", "weak", "looking for a brave knight", "crushed by housework", "romantic", "inexperienced", "not thinking about consequences", "fleeing from domes- 
tic violence or humiliation", and "uneducated". At the same time, a potential recruiter was described as a "smart psychologist" who "knows how to win the trust of a girl" and "capable of brainwashing easily".

Perhaps the "rhetoric of unreasonableness" in respect to those who left and the description of recruiters as "smart psychologists" whom no one can resist is in fact an attempt to rationalize the recruitment of women to war and to describe them as victims. This is also confirmed indirectly by the respondents in the following narratives: "well, she followed her husband, and what else could she do, he was her husband", or "[She was] a very smart girl, she was so modest, and these recruiters are very talented, this is how it works".

\section{Conclusion}

In general, the discourse analysis of female students' narratives shows that they see the following drivers of online recruitment of young women as dominant:
1. willingness to share the fate of her husband and thereby to prove her devotion to her marital and religious duties;

2. gender inequality, which in traditional local communities make women perceive terrorism as a palatable act of "equalization" with men in their struggle "for the purity of the faith";

3. domestic violence as a factor used by extremists for the recruitment of their victims;

4. search for a romantic hero, striving for a happy marriage is one of the appeals of propaganda;

5. loneliness, the search for a purpose in life, an attempt to diversify one's daily routine.

This study suggests that gender psychology and discourse analysis professionals should make more contributions in research on terrorism issues. It is important to strengthen preventive work with girls and to involve gender psychologists who are thematically trained as well as familiar with the skills and tools used by online recruiters.

\section{About the Author}

Lydia U. Kurbanova is Professor of Sociology at the Chechen State University in Grozny, Russia.

\section{References}

- Borell, Klas (2008) “Terrorism and Everyday Life in Beirut 2005: Mental Reconstructions, Precautions and Normalization.” Acta Sociologica 51(1): 55-70.

- Gubrium, Jaber F., and James A. Holstein (2009) Analyzing Narrative Reality, Los Angeles: SAGE Publications.

- Hilgartner, Stephen and Charles L. Bosk (2007) “The Rise and Fall of Social Problems: Concept of Public Spaces." In Social Problems: Constructivist Reading, Kazan: Publishing House of Kazan University, WITH, 145-84.

- Ibarra, Peter R. and Michael Adorjan (2017) “Social Constructivism." In The Cambridge Handbook on Social Problems, Cambridge: Cambridge University Press, 279-300.

- Ibarra, Peter and John Kitsyuz (2007) “Claims Discourse-Requirements and Vernacular Resources.” In Social Problems: Constructivist Reading, Kazan: Publishing House of Kazan University, 55-115.

- Jenkins, Philip (2003) Images of Terror: What We Can and Can't Know about Terrorism, New York: Routledge.

- Polach, D. (2010) “Social Issues With a Constructivist Point of View." Journal of Social Policy Studies 8(1): 7-12.

- Yarlykapov, A.A. (2016) "The 'Islamic State' and the North Caucasus in the Middle East: Challenges and Lessons for Russia." International Analytics 3(17): 112-21. 


\title{
The Potential of Families in Countering Violent Extremism in the North Caucasus
}

By Victoria Gurevich, The Ohio State University, Columbus

DOI: $10.3929 /$ ethz-b-000426379

\begin{abstract}
While cadres of professionals have been mobilized and trained to engage with the violent extremist threat in the North Caucasus, families - those closest to the vulnerable people countering violent radicalization (CVE) work tries so hard to reach-have been ignored, blamed, and left to navigate perhaps the most difficult moment of their lives alone. This article identifies what makes families unique in their capacity to influence loved ones, addresses some common misconceptions about their role in the radicalization process, and highlights some potential challenges of family involvement in CVE. The article draws on empirical evidence from various international studies and programs and analyzes its applicability in the North Caucasus context.
\end{abstract}

\section{Introduction}

Radicalization and violent extremism have affected the North Caucasus for decades. In all the waves of violence-through the separatist movements to ISIS's recent terrorist attacks — the approaches to combatting insurgents has been largely within the control of security agencies and law enforcement. While methods had traditionally been heavy-handed, beginning around 2010 soft measures were introduced in Dagestan and Ingushetia which included liberalization of the regime towards lawabiding Salafis, efforts at facilitating dialogue between Sufi and Salafi communities, and commissions for the rehabilitation of fighters. These measures were successful and visibly reduced the outflow of young radicals to the insurgency, however, they were rolled back in the lead-up to the Sochi Olympics in early 2013. Furthermore, the introduction of some soft-measure elements did not bring about a change in the general strategy that continued to rely on heavy-handed approaches.

In the last five years or so, the fight against radicalization in the North Caucasus witnessed a fundamental shift in thinking as to how radicalism and violent extremism are most effectively combatted. Instead of fighting radicalization exclusively through investigations and counter-terror operations, CVE approaches began to engage individuals before they radicalized, while they could still be turned away from radical narratives. In some republics, various civil society groups and NGOs have gradually made a seat at the table for themselves, introducing a new toolbox of soft-power messaging and programming. However, despite the broadening of CVE actors and activities, there remains a layer of prevention that has not been sufficiently accessed or empowered: the family. Families are uniquely positioned to support countering violent extremism, yet in the North Caucasus they have not been adequately included in CVE efforts.
The authorities in the North Caucasus have come to recognize the important role of families; as such, parents and other family members have begun to receive some attention when it comes to their potential to protect their loved ones from radicalization; however, progress has been slow and superficial. This article introduces theoretical perspectives and empirical evidence in support of the argument for greater family involvement in CVE in the North Caucasus and offers suggestions for how to achieve it. Evidence is supported by analysis through three sections that focus on understanding the role of families, the misconceptions surrounding their involvement in radicalization, and the challenges that their inclusion may bring.

\section{Why (Not) Families}

Countering Violent Extremism (CVE) is a catch-all description that refers to non-coercive attempts to change attitudes and behaviors about using violence for political objectives. Because there is no internationally (and even at times nationally) defined standard for CVE, programs "throughout the world vary, from projects aimed at changing behavior to ones that challenge ideas and beliefs, to activities aimed at building social cohesion" (Harris-Hogan, Barrelle and Zammit 2016, 6). Despite this diversity of engagement, however, theories of resilience have almost exclusively focused on the individual and have not paid attention to contextual effects from the structures and institutions one is shaped by. Perhaps the most important context in which one exists, positionality in one's family, has been virtually unexplored. Why?

Conduct within the family is difficult to operationalize; as such, the sponsoring agencies and organizations that develop CVE have not prioritized the family space. To start, it is difficult to conduct family-centered 
research in any context, much less with a security sensitive focus such as radicalization. Furthermore, each family has its own history, vulnerabilities, trauma, and interpersonal dynamics; as such, designing a family-oriented CVE program that is effective for everyone while also accommodating a range of circumstances is no small task. Most importantly however, it is not only a matter of access to the family, but a matter of timing - the fundamental challenge of all prevention work is identifying a worrisome change in behavior before it is too late. To expect families to definitively "know" when to call for help is an impossible barrier to entry. For these reasons and more, the family environment has not been a central focus of most CVE programming, with research and intervention instead focusing on more predictable and structured spheres of influence and working with community members such as teachers, imams, sports coaches, social workers, psychologists and other community and youth leaders.

Recently, "researchers and practitioners have recognized the importance of ensuring that families are addressed as a prevention target, as well as recognizing the valuable resource that they represent in preventive efforts" (El-Amraoui and Ducol 2019, 190). The incorporation of families into the cadre of CVE professionals not only expands the network of CVE actors, but it also enables a new front of CVE work that leverages the inimitable qualities of families that no governmental, civil society, or professional group can replicate.

\section{Inimitable Qualities of the Family}

Individuals both influence and are influenced by their families; individuals change and grow within a family context as do the relationships between parents, children, and siblings. In regard to radicalization, there are several important factors that can make families a unique and irreplaceable resource and connection. To start, the family often has personal and frequent access to the vulnerable individual in the home. Whereas traditional CVE efforts often have an air of officiality, especially in the North Caucasus where lectures are often delivered by staid police officers, educators or imams, the home can allow families to connect in a less structured and formal setting. The other inherent strength of families is the continuity that they share with the vulnerable individual. Individuals are vulnerable to radicalization for very personal reasons, "to divert an individual on this path, it is crucial to understand their environment, as well as their individual psychology" (UNESCO 2019). Only families can possess a deep history of a person-they know what they have experienced, the traumas in their life, and what their aspirations may be. The North Caucasus history of insurgency and war has left many families with deep trauma that has been passed through gener- ations - these memories and legacies influence an individual's composition in intimate and subtle ways.

Families have an emotional attachment that professional groups cannot imitate. In the North Caucasus, mothers in particular have a long record of going to great lengths to fight for their children's lives and security. Most importantly, families are instrumental in shaping attitudes of their children. While countering violent extremism implies that the radicalization process has already started and must now be reversed, families have an opportunity to foster resilient attitudes in the home to prevent radicalization from ever taking root in the first place. A 2015 study by the RAND Corporation named "What Factors Cause Youth to Reject Violent Extremism?" found that family plays a greater role than friends in shaping attitudes toward nonviolence (Cragin et al. 2015). While peer groups may influence the radicalization of young people, it is the influence of the family that affects their willingness to engage in violence. While current CVE programming works primarily with individuals who have been identified as atrisk, by enabling the family, specifically parents, to act as CVE actors, resilience can be fostered within the children before any vulnerabilities emerge.

Families undoubtedly play a unique role in the lives of their loved ones. They are educators, guides, confidants, and helpers; they raise the next generation and are reservoirs of legacy and promulgators of values. North Caucasus societies have very thick and rich kinship networks, especially in Chechnya, Ingushetia, and Dagestan, which have the highest birth rates in Russia. Families are big and often reside together in kinship enclaves in villages and towns; respect for elders is pronounced and carries a high social value. Yet for all their inherent potential, families have been underutilized in CVE work or utilized in the wrong fashion. Particularly in Chechnya, there are some significant misconceptions to the role of families in the radicalization process that have led families to be regarded with suspicion, blame, and mistrust, and even be subjected to violence.

Across the North Caucasus, the primary target for family programming are those with radicalizing youththose who have plausibly demonstrated an ideological openness and perhaps even behavioral adherence to extremist narratives. The methods used across the republics are largely the same uncreative lectures; they emphasize what parents should do but they do not actually teach parents the information and skills that would make them effective sources of counterinfluence. Despite a similar conversational approach to family involvement in CVE, the tones that authorities strike across the republics range from ineffectual to detrimental. In Chechnya, the standard format for engaging families involves sporadically gathering parents together and having author- 
ities lecture them on why and how they should "control" their children better. These lectures often strike an accusatory tone, suggesting that the parents are to blame for the decisions of their children. Internet security is often a significant emphasis of these lectures, as is the importance of developing in the younger generation a proper "spiritual and moral education." In Ingushetia, official CVE rhetoric directed at parents is softer and more approachable, however, the substance of the family programming remains largely ineffectual. Specifically, policies in Ingushetia have focused on urging parents to convince their children of the error of their ways; authorities have emphasized the possibility for those fighting in extremist groups to return to a peaceful life if they reject radical sentiments and repent. Although these programs ostensibly offer generous and nonpunitive support for involvement in violent extremism, levels of trust in the republic remain considerably low.

\section{Common Misconceptions}

A significant barrier to expanding the role of families in CVE is the misconceptions and suspicion that many people have about the role of families in radicalization. For many of the same reasons that were mentioned above as to why families can be strong positive source of counterinfluence, those same factors can be cause for suspicion. Take for example the strength of emotional attachment: while on the one hand the fact that families share deep emotional attachment with a vulnerable person can make them work tirelessly to ensure their safety, that same logic can be extended to suspect that families will also conceal the radicalization of a loved one in order to protect them.

However, suspecting families to be accomplices overlooks the fact that "Families are often the people most impacted by acts of violent terrorism and recruitment to extremist ideas. They are the first hit with loss and pain after a terrorist act and feel deep pangs of shame and guilt when a loved one becomes radicalized" (Rafiq 2018, 8). The Kadyrov regime in Chechnya is particularly prone to this fallacy; families of (suspected) radicals are often held accountable for the behaviors of loved ones and are often forced to publicly condemn their behavior and disown them, and in extreme cases family members can also have their homes burnt down by the regime, be exiled, subjected to torture or taken hostage (CAPC 2019).

Before suspecting families to be complicit in the radicalization of a loved one, it is important to note that the signs of radicalization can be far from obvious; it is wrong to assume that families that failed to spot the early signs of extremism are inattentive, that they do not care, or that they are sympathetic to radical messaging. Not only are the signs of change difficult to notice, behav- ioral changes do not obviously point to radicalization. Adolescence is characterized as a period of great change; young people at this stage in their lives are expected to be rebellious, to challenge authority, experiment with religion, and to demand more privacy in their lives. For example, in Dagestan, youth who are frustrated with the widespread abuse of power and corruption in the republic can reach the seemingly logical conclusion that secular governance is oppressive, and instead support alternative forms of justice as advocated through customary and sharia law. This in itself is not an unfounded proposition as the corruption of the clan system in Dagestan is rampant; radicalization as it stems from injustice can thus be difficult to identify.

Furthermore, some of the changes that can in hindsight be a sign of radicalization can in the moment be cause for relief. "Parents sometimes feel secure and relieved when their child turns away from drugs and embraces Islam instead. From then on, there is no smoking, no drinking, no sleeping until noon" (Schlaffer and Kropiunigg 2015, 20). In Chechnya, strict rules of Islamic behavior-such as a dress code and prohibitions on alcohol-are enforced by the Kadyrov regime such that a turn towards an Islamic code of conduct is not unusual in and of itself, it can be indicative of many things. Knowing what behavioral changes to take seriously is a fundamental challenge of CVE work that virtually every organization and agency has struggled to accurately classify.

Finally, even if radicalization is suspected, responding can be a daunting task. To believe that a loved one is radicalizing means acknowledging the possibility of losing them, your own cluelessness of how to help them, and the risk that they and the rest of your family may face from the security services. While families are positioned to serve as educators, protectors, and confidants, they do not necessarily have the skills to engage effectively. Like any other professional group working in the CVE space, families need to be taught the information, language, and techniques that are used in the countering violent extremism portfolio. Without the proper skills to intervene, families are often left feeling helpless in their ability to bring their loved ones back from the path of radicalization.

\section{Challenges}

Despite the need to bring families into the CVE space there are many potential and real challenges of doing so. To start, given how difficult it is to not only identify radicalization but also to respond to it, it is likely that there will be divergent opinions on how to react. For example, suspecting radicalization, one parent may want to seek professional help while the other parent denies the signs altogether. Or, if they both identify radicalization 
but one parent wants to consult professionals while the other parent wants to deal with this themselves, how do they proceed? North Caucasus tradition, in some republics more than others, dictates strict aloofness in the relationship between a father and his children, which consequently limits parents' capacity to speak sincerely about certain issues with their maturing children, to debate with them, and hinders their ability to notice changes in their worldviews. Moreover, wives oftentimes do not have the sufficient power or community support to address the radicalization of their husbands and are fearful of reporting it once things get really bad.

Bringing families into the CVE space can also be challenging because family members can be part of the problem that contributed to radicalization in the first place. It is often the case that vulnerable youth come from troubled homes where there is active or unresolved sources of trauma, pain or domestic violence. CVE targeted programming in the North Caucasus focuses on individuals from "socially underprivileged, incomplete and dysfunctional families," many of whom find themselves in difficult circumstances due to the legacy of insurgency in the region, which has contributed to significant and unaddressed trauma (CAPC 2019). Families of former fighters (defined as deceased or convicted) in particular can find themselves under immense pressure from the republican and security authorities, pressure which can exacerbate grievances and trauma and contribute to destructive behaviors. It is important to note that "experiencing an unstable family environment does not guarantee involvement in VE or any other criminality" (Simi, Sporer and Bulboz 2016, 546). Due to the relative insularity of the home, however, it may be difficult for professionals to entrust CVE responsibilities to an environment that at best unknown, or at worst dangerous.

Perhaps the most difficult terrain to navigate is contact with the security services. The lack of trust between families, local communities, and local and federal authorities makes establishing cooperative relationships and good-faith information sharing difficult. A climate of fear surrounding contact with security services is pervasive across the region given the systematic and grave human rights violations reportedly committed by security services in all of the republics, including torture, enforced disappearances and falsification of criminal cases. The situation is the worst in Chechnya due to a long history of persecuting families of radicals, but is also severely dysfunctional in Dagestan given its use of profuchet, or a preventive registration list for "suspected" religious extremists. The list is largely an exercise in stereotyping and the threshold for being added to the list is low. At its peak in 2015 the profuchet list reportedly had over 16,000 names, including nearly all family members of former fighters. Being on the list led to detentions at checkpoints and borders, forced appearances at police stations, and a slew of other harassments (CAPC 2019). While the list was reported to have been dissolved in 2017, reporting from Dagestan indicates that it is still active. As such, concerned families may be reluctant to reach out for help out of fear that by disclosing their concerns they will be subject to a life of harassment.

\section{Ways Forward}

Radicalization and violent extremism have complicated origins and thus require comprehensive approaches that engage a broad range of CVE actors such as psychologists, police officers, social workers, theologians, teachers, and, as this article argues, families. For a long time, CVE work in the North Caucasus involved primarily heavyhanded, top-down approaches that were sponsored by security agencies and local police forces. The expansion of the CVE network to include civil society actors was unequivocally a positive step for prevention work. The incorporation of families must be the next one.

Many creative and inspiring CVE practices have been successfully developed to support prevention efforts; that same level of energy and dedication must now be directed at improving family involvement. The ideas listed below will require collaboration between families and the entire network of CVE stakeholders and professionals. These suggestions are general and should be tailored to specific local and republic contexts.

- Develop more interactive training courses for parents to learn about their role in countering the influence of violent extremism. These courses should move past a lecture model and educate parents on the psychology of adolescence, how to discuss difficult issues with their children, and how to recognize possible signs of radicalization, how to intervene, and where to seek help. These lessons must be gender sensitive, focusing on the similarities but also the divergences between the recruitment and ideological narratives targeted at boys and girls.

- Train parents in internet security. Simply put, many parents are computer literate and are not familiar with the countless media platforms and forums where their children may come across radical ideologies. Parents should be made aware of the key arguments and images that recruiters use and prepare counter arguments for the material. While delivering counter narratives is always difficult, reducing information asymmetries is a critical step to improving communication.

- Make psychological health resources more available for both parents and children. Free counseling should be accessible to families and vulnerable youth 
and must not be stigmatized or securitized. Radicalization often occurs in families where there are problems and unresolved traumas; CVE may not be effective so long as the personal wounds of individuals go unhealed. Furthermore, individuals who have previously experienced the radicalization of a loved one are great resources and intermediaries as they can identify with the personal experience.

For more information and recommendations for improving family involvement in CVE in the North Caucasus, see the Conflict Analysis and Prevention Center's recently released methodological cards. ${ }^{1}$

\section{About the Author}

Victoria Gurevich, is a Ph.D. student specializing in International Relations at the Department of Political Science, The Ohio State University, Columbus, United States.

\section{References}

- Cragin, Kim, Melissa A. Bradley, Eric Robinson, and Paul S. Steinberg (2015) What Factors Cause Youth to Reject Violent Extremism? Results of an Exploratory Analysis in the West Bank, Santa Monica, CA: RAND Corporation.

- El-Amraoui, Anaïs F, and Benjamin Ducol (2019) "Family-Oriented P/CVE Programs: Overview, Challenges and Future Directions.” Journal for Deradicalization 20: 190-231.

- Haras, Rafiq (2018) The Role of Women in Countering Violent Extremism, United States House of Representatives.

- Harris-Hogan, Shandon, Kate Barrelle, and Andrew Zammit (2016) "What Is Countering Violent Extremism? Exploring CVE Policy and Practice in Australia.” Behavioral Sciences of Terrorism and Political Aggression 8(1): 6-24.

- Morgan, Dave Hedley (1996) "Family Connections: An Introduction to Family Studies."

- UNESCO (2019) "Reconstructing Childhood: Investing in Teachers to Stop the Re-Seeding of Violent Extremism in Mosul's Primary Schools - Iraq." ReliefWeb.

- Schlaffer, Edit and Ulrich Kropiunigg (2015) "Mothers against Terror." per Concordiam: Journal of European Security and Defense Issues 6(4):18-25.

- Simi, Pete, Karyn Sporer, and Bryan F. Bubolz (2016) "Narratives of Childhood Adversity and Adolescent Misconduct as Precursors to Violent Extremism: A Life-Course Criminological Approach." Journal of Research in Crime and Delinquency 53(4): 536-63.

- Sokirianskaia, Ekaterina (2019) “Will new waves of radicalization in the North Caucasus be prevented?" Conflict Analaysis and Prevention Center.

1 https://secureservercdn.net/160.153.138.163/ppf.da0.myftpupload.com/wp-content/uploads/2020/04/doklad_2020-1_compressed.pdf (accessed 13 May 2020). 


\title{
Preventing Violent Extremism in the North Caucasus: The Case of the Regional Project “Together!” (“Vmeste!”)
}

\author{
By Mareta Dzeitova, Ingush State University, Magas
}

DOI: $10.3929 /$ ethz-b-000426379

\begin{abstract}
The problem of radicalism and extremism has manifested itself in many different parts of the world and is usually associated with social tensions, civil unrest and violent conflict. The North Caucasus region is no exception. This article aims to analyze the context in which processes of prevention work take place through the prism of the experience of the Genesis Fund, a North Caucasus NGO that has been engaged in such work since 2005. The article describes the formats and methodologies of countering violent extremism (CVE) activities with youth and shares some of their results in the region. The experiences of many initiatives implemented in the North Caucasus are especially interesting and important given that the region has been home to protracted armed conflict for many years, and that North Caucasus youth are still the focus of attention for recruiters from various extremist and radical groups.
\end{abstract}

\section{The Pressing Problem of Youth Extremism}

The forms and contexts of violent extremism and radicalism vary across different parts of the world but are largely associated with social tensions that go hand in hand with unrest and armed conflict. The North Caucasus is no exception. Radicalization and extremism have led to significant violence in this region.

The NGO Genesis was originally confronted with the issue of radicalization and extremism in 2005-2007 while implementing a joint project with UNICEF. For several years, this issue has been acute. Genesis specialists and psychologists were regularly approached by school teachers, youth workers, and parents. The questions were similar: "How can we stop the radicalization of youth?", "How can we teach our youth to think critically and minimize the influence of Wahhabism?"

In October 2012, the Advisory and Analytical Council for the Prevention of Extremism was established by Yunus-Bek Yevkurov, the then head of Ingushetia. A representative of Genesis joined the council at a time when the issue of extremism and radicalization were recognized at all levels. Numerous social, economic and cultural programs made youth a key focus group. Later, a similar council was created in Chechnya and the coordinator of Genesis projects in the Chechen Republic became a member.

\section{The Role of NGOs in Countering Extremism}

It is an important and promising sign that the role of NGOs in countering extremism has changed. Formerly, anti-extremism, counter-terrorism, and counter-radicalization efforts were considered to be mostly the prerogative of the security services. However, it soon became obvious that it was impossible to deal with the issue with coercive methods exclusively.

In 2013, Genesis conducted research for the World Bank in five republics of the North Caucasus ("Research of the vulnerabilities in the North Caucasus"). Ninety percent of respondents mentioned radicalization and extremism among the most serious and pressing problems of the region. Most respondents believed that the main reason for radicalization is deep distrust of the authorities, lack of open social dialogue and limited possibilities for young people to articulate and solve their problems. "There is a wall of alienation and mistrust between youth and authorities in the region," as one respondent described the situation.

Experts point out that in the national republics of the North Caucasus, radicalism and extremism manifest themselves not only through participation in armed groups but also through grassroots extremism aimed towards local ethnic and religious minorities. Minority representatives, namely, members of Russian, Greek, Armenian, Tatar, Roma, and other communities, report that they as well as their children face discrimination and marginalization in their places of residence and educational establishments.

In other regions of Russia, clashes between the youth of Caucasian origin (students, labor migrants, etc.) and the local population also contribute to the problem. Oftentimes the youth, especially from Dagestan, Chechnya and Ingushetia, are not ready for nonviolent or equal interaction with representatives of other cultural groups. The phenomenon is often explained by the isolation and violence they have experienced, as well as the region's economic backwardness caused by two Chechen wars, repression, terrorism and longterm instability. 


\section{Addressing the Problem of Youth Radicalization}

According to our experts, trainers, psychologists and active volunteers, there are several general characteristics of modern youth with regards to CVE:

- even though young people are an immediate target, as well as a direct victim of terrorism and radical recruiters, in many cases they are very passive;

- they assess most information through the lens of its practical applicability in daily life and its use for personal success;

- most of them are willing to participate in CVE events, but only if they are organized and conducted by someone else;

- young people are mostly motivated by some direct benefits (like trips, grants or awards); many do not consider the opportunity to gain knowledge, new experience or contacts, or personal development, to be "profitable" even if it brings dividends later.

According to experts working with youth in the North Caucasus, a systematic approach is required to address the problem of youth radicalization, which would include both educational methods and the opportunities for youth to speak out and be heard-the latter being the most important. It is crucial to involve representatives of major faiths and religions in this activity due to the fact that the content of extremism and radicalization in the region is often promoted under the banner of religion. Spiritual leaders of different denominations should deliver true messages and philosophies of the world religions, emphasizing the inadmissibility of violence and terrorism.

\section{The "Together!" Project}

The Genesis team was deeply concerned about the problem of youth radicalization and the growth of extremism in the North Caucasus. As a result we developed the "Together!" project. It focused on empowering and building the capacity of civil society, developing constructive civil dialogue to prevent radicalism and extremism among young people through the establishment of an information platform, and facilitating a dialogue among the government, civil society, clergy of various faiths and youth.

The project is guided by our own experience and the analysis of international agencies that studied the issue of youth extremism and radicalism. According to the Department of Communities and Local Government's research (UK, 2010), there are two types of successful interventions in youth development: capacity building or empowerment of young people, and edu- cation and training that can challenge theologically based ideologies. ${ }^{1}$

While developing the project, we considered both the specificity of our youth and the recommendations of experts. Interactive methods like trainings, discussion meetings, case-studies, quests, and forum theatres, among other activities, are used. A wide range of youthspecific topics are covered:

- communication and non-violent conflict resolution,

- intercultural and interfaith communication and tolerance,

- counter-manipulation behavior, including in online forums,

- leadership and team building,

- social project design, and

- public speaking skills and creating public campaigns. This project provides an opportunity for young people to participate in creativity contests and cultural festivals of different ethnic groups. An applied academic conference "Academia and Education for the Prevention of Extremism and Radicalism" was organized for young scholars.

The project is implemented in four republics of the North Caucasus: Dagestan, Chechnya, Ingushetia, and Kabardino-Balkaria. Weekly youth trainings are our main type of activity. Other formats are more time and resource consuming and therefore take place every 3-4 weeks.

Project updates are published on the Genesis website and social media, like Facebook, VKontakte, and Instagram, because these three are the most popular in the region. The main aims are:

- to inform society about the project and to provide visibility for it,

- to attract youngsters who would like to participate in such activities, but don't know how to get involved,

- to encourage activists and motivate them, and

- to create a volunteer database for other organizations and projects.

Aside from organizational work, local project coordinators are invested in all the events personally. They act as mentors, friends, and protectors for our volunteers. It is not the designed goal of the project, but the consequence of it. We believe that the project values and the work atmosphere that our team has tried to create are the main reasons for it.

Communication with government agencies and spiritual leaders has been an important part of the project. Government agencies provided administrative support to the events and joined the discussions; at the same time they were also provided with advice and training for their own activities. Religious leaders explained to

1 https://www.researchgate.net/publication/272348701_Preventing_Religious_Radicalisation_and_Violent_Extremism_A_Systematic_ Review_of_the_Research_Literature/download (accessed 13 May 2020). 
our participants that all the main world religions are non-violent and reject terrorism and that they spread the narratives of wisdom, mercy, forgiveness, and peace.

\section{The Creation of Youth Networks}

Experience has shown that the best way for engaging youth in public activities is the creation of youth networks. It provides young people from different regions, republics and social groups with strong and vibrant ties. The networks are highly effective in ensuring community mobilization when young people actively interact with their environment, which can include family, relatives, friends, elders, community leaders, clergy, civil society, and business professionals who can become influential agents of change. Ultimately, the network is the source of new initiatives and leaders. Girls and women play a critical role here but their capacity has been underestimated for CVE activities. By creating alternative reference groups for youth, networking can make CVE efforts more successful and help the participants turn their backs to extremist groups.

A networking format for youth work is not new for the North Caucasus; however, it requires time and significant funds to build a network. It should be sustainable after external support is terminated, which is the most difficult aspect of the project. As such, youth networks are rare in the region.

Within the framework of the "Together!" Project, a new network has been created. It is supported by the resource centers in the four republics of the North Caucasus and organizes at least 100 peer-to-peer events with some 3,000 participants annually.

\section{Impact}

Since 2014, Genesis conducted annual research within the framework of the "Together project". Its aim is to measure the level of youth awareness about the causes of extremism and their interest in anti-extremism and antiradicalism efforts. In addition, the dynamics of youth's opinions and attitudes were monitored.

According to the results, the number of people aware of extremism has increased from 2014 to 2019. The vast majority of the respondents have a negative attitude towards it; some half of the respondents define extremism through extremely negative value judgments (illegal actions or extreme intolerance).

Over half the respondents associated the rise of extremism with social and political reasons, like social inequality, struggling for survival on the labor market, low credibility of law enforcement agencies, the declining influence of national cultures, and the influence of mass media. Immaturity, distorted values of youth, and mental disorders were also mentioned as possible reasons for extremism.

In general, the results of the research reflect the main vulnerabilities of modern society. Most participants are deeply concerned about the issue.

It is noteworthy that the majority of respondents appreciated the importance of preventive activities and were interested in joining them. At least 2,000 people from four republics of the North Caucasus and 30-50 experts, like academics, government youth specialists, and representatives of law enforcement agencies, took part in the annual research.

\section{Conclusions}

We are often asked about the reasons for our project's popularity and sustainability. The experience and certain fundraising skills of the organizers made a difference, for sure. We should pay tribute to our wonderful donors. I believe the projects' core principle, "Do no harm!", is the key to success. The ideas of tolerance and pluralism are the cornerstone of our events. We do not impose the "truth" but present our participants different opinions and positions. Non-violence and freedom of choice are attractive for the youth, and it motivates them to get involved and spread the ideas of non-violence.

Also, sincerity and honesty are a must when working with youth! They sense a phony a mile away. We always bear that in mind; and if we don't know the answer, we just talk about it honestly and try to find the answer together.

We also try to use informal and creative methods for the prevention of violent extremism. We believe that activities should use appropriate language and tools understandable for the target audience. They should be disseminated by all possible means: interactive education, mass media, social media, videos, etc.

Genesis, like any other NGO, cannot address the problem of unemployment or provide access to material resources. But if we provide the youth of the North Caucasus with knowledge and life skills, they will be able to withstand the destructive influence of radical and extremist groups or acts. To this end, our team suggests informal approaches to overcome social apathy and alienation and for shaping a positive identity that is grounded in dignity and usefulness.

\section{About the Author}

Mareta Dzeitova, Ph.D., associate professor of psychology, Ingush State University. She is also the supervisor of educational programs at the NGO Genesis. 


\section{ABOUT THE RUSSIAN ANALYTICAL DIGEST}

Editors: Stephen Aris, Matthias Neumann, Robert Orttung, Jeronim Perović, Heiko Pleines, Hans-Henning Schröder, Aglaya Snetkov

The Russian Analytical Digest is a bi-weekly internet publication jointly produced by the Research Centre for East European Studies [Forschungsstelle Osteuropa] at the University of Bremen (www.forschungsstelle.uni-bremen.de), the Center for Security Studies (CSS) at the Swiss Federal Institute of Technology Zurich (ETH Zurich), the Center for Eastern European Studies at the University of Zurich (http://www.cees.uzh. ch), the Institute for European, Russian and Eurasian Studies at The George Washington University (https://ieres.elliott.gwu.edu), and the German Association for East European Studies (DGO). The Digest draws on contributions to the German-language Russland-Analysen (www. laender-analysen.de/russland), and the CSS analytical network on Russia and Eurasia (www.css.ethz.ch/en/publications/rad.html). The Russian Analytical Digest covers political, economic, and social developments in Russia and its regions, and looks at Russia's role in international relations.

To subscribe or unsubscribe to the Russian Analytical Digest, please visit our web page at http://www.css.ethz.ch/en/publications/rad.html

Research Centre for East European Studies at the University of Bremen

Founded in 1982, the Research Centre for East European Studies (Forschungsstelle Osteuropa) at the University of Bremen is dedicated to the interdisciplinary analysis of socialist and post-socialist developments in the countries of Central and Eastern Europe. The major focus is on the role of dissent, opposition and civil society in their historic, political, sociological and cultural dimensions.

With a unique archive on dissident culture under socialism and with an extensive collection of publications on Central and Eastern Europe, the Research Centre regularly hosts visiting scholars from all over the world.

One of the core missions of the institute is the dissemination of academic knowledge to the interested public. This includes regular e-mail newsletters covering current developments in Central and Eastern Europe.

The Center for Security Studies (CSS) at ETH Zurich

The Center for Security Studies (CSS) at ETH Zurich is a center of competence for Swiss and international security policy. It offers security policy expertise in research, teaching, and consultancy. The CSS promotes understanding of security policy challenges as a contribution to a more peaceful world. Its work is independent, practice-relevant, and based on a sound academic footing.

The CSS combines research and policy consultancy and, as such, functions as a bridge between academia and practice. It trains highly qualified junior researchers and serves as a point of contact and information for the interested public.

The Institute for European, Russian and Eurasian Studies, The Elliott School of International Affairs, The George Washington University The Institute for European, Russian and Eurasian Studies is home to a Master's program in European and Eurasian Studies, faculty members from political science, history, economics, sociology, anthropology, language and literature, and other fields, visiting scholars from around the world, research associates, graduate student fellows, and a rich assortment of brown bag lunches, seminars, public lectures, and conferences.

The Center for Eastern European Studies (CEES) at the University of Zurich

The Center for Eastern European Studies (CEES) at the University of Zurich is a center of excellence for Russian, Eastern European and Eurasian studies. It offers expertise in research, teaching and consultancy. The CEES is the University's hub for interdisciplinary and contemporary studies of a vast region, comprising the former socialist states of Eastern Europe and the countries of the post-Soviet space. As an independent academic institution, the CEES provides expertise for decision makers in politics and in the field of the economy. It serves as a link between academia and practitioners and as a point of contact and reference for the media and the wider public.

Any opinions expressed in the Russian Analytical Digest are exclusively those of the authors. Reprint possible with permission by the editors.

Editors: Stephen Aris, Matthias Neumann, Robert Orttung, Jeronim Perović, Heiko Pleines, Hans-Henning Schröder, Aglaya Snetkov Layout: Cengiz Kibaroglu, Matthias Neumann, Michael Clemens

ISSN 1863-0421 @ 2020 by Forschungsstelle Osteuropa an der Universität Bremen, Bremen and Center for Security Studies, Zürich

Research Centre for East European Studies at the University of Bremen • Country Analytical Digests • Klagenfurter Str. $8 \cdot 28359$ Bremen • Germany Phone: +49 421-218-69600 • Telefax: +49 421-218-69607• e-mail: laender-analysen@uni-bremen.de•Internet: www.css.ethz.ch/en/publications/rad.html 